Gavurova, B., Mikeska, M., Huculova, E. (2020). Evaluation of selected determinants of public procurement in the health sector. Administratie si Management Public, 34, 45-63, DOI: $10.24818 / \mathrm{amp} / 2020.34-03$

\title{
Evaluation of selected determinants of public procurement in the health sector
}

\section{Beata GAVUROVA ${ }^{1}$, Martin MIKESKA ${ }^{2}$, Eva HUCULOVA ${ }^{3}$}

\begin{abstract}
This article aims at anexaminationof the impact of the number of public procurement tenders in the healthcare sector on the final purchase price. We used the data from 1544 public contracts related to the acquisition of health technologies for the years 2014-2017. The highest number of public contracts was reached at level of 501 in 2014, and the lowest number was 238 in 2017. The highest average value of estimated and final prices was found in 2015. The proportion of tenders submitted with only one tenderer was over $39 \%$. For the analysis, we used a generalized linear model and quantile regression. The results showed that, as the number of bids increased by one unit, the ratio of final and projected price on average would change 0.975 times, which means an increase in savings by $2.45 \%$. Using quantile regression, we modelled the influenceof the explanatory variables on the individual quantiles of the explained variable instead of the conditional mean. The aim was to determine the impact of the number of proposals at everyovercharge level. As the order value of the quantile increases, the effect of offers on generating savings in public procurement is gradually decreasing. For more than $40 \%$ of the most overpriced orders, the number of offers does not have a statistically significant effect on the size of the savings. With $25 \%$ of the most economical orders with an increasing number of bids by one unit, savings of $4.77 \%$ were achieved. However, increasing the number of procurement contracts to create savings in public procurement may develop differently over time. By applying the generalized linear model, we found that in 2014 the increase in the number of offers by one unit had an impact on the average increase in public procurement savings of $7.15 \%$. In 2015, this impact fell to $1.59 \%$. In 2016, the growth in the number of proposals did not have a statistically significant impact on the average increase or decrease in savings. In 2017, this value increased slightly above $1.96 \%$. Public acquisition processes will continue to be a critical pointfor the efficient allocation of public resources.
\end{abstract}

Keywords: public procurement, public contract, savings, overpricing, quantile regression, sector efficiency.

\section{JEL: H40, H54}

DOI: $10.24818 / \mathrm{amp} / 2020.34-03$

\footnotetext{
${ }^{1}$ Professor, Ph.D., MBA, Center for Applied Economic Research, Faculty of Management and Economics, Tomas Bata University in Zlín, Zlín, Czech Republic, email: gavurova@utb.cz. Corresponding author.

2 Ph.D., Department of Economics, Faculty of Management and Economics, Tomas Bata University in Zlín, Zlín, Czech Republic, email: mikeska@utb.cz.

${ }^{3}$ Ph.D., Technical University of Kosice, Slovak Republic, email: eva.huculova@tuke.sk.
} 


\section{Introduction}

Public procurement processes play an essential role in each country's economy and budget. They influence the efficiency of the public sector and through which the public sector funds are allocated. One of the key sectors that has been a subject to various analyzes of procurement efficiency in recent years is the healthcare sector.Throughout the European Union the structure of budget expenditures on healthcare from the point of view of GDP is quite homogeneous. Countries below $5 \%$ of GDP spendings on healthcare are represented by Cyprus, Hungary, Romania, Latvia, and Estonia. Special position of less than $2.5 \%$ of GDP spending healthcare probably because of unique healthcare character and of high GDP belongs to Switzerland. The western European countries + Czechia and Slovakia mostly spend more than $7 \%$ of GDP on their healthcare system. Fig. 1 illustrates the average annual expenditures when the EU28 spend on healthcare from $6.7 \%$ of GDP in 2008 to $7.0 \%$ of GDP in 2018. The Czech economy, which had practically identical healthcare system with Slovakia until 1995, in fact copies the expenditures of the European average. Recent fundamental changes in the trend of financing the Slovak healthcare system were brought by global economic crisis and the follow-up sales crisis, especially in the automotive industry. The unemployment rate after 2009 exceeded the $10 \%$ threshold and reached $14 \%$ in the long run. The drop of economic performance, lower insurance contributions and lower selected taxes changed the structure of budget income. From the point of view of the investigated issues, they influenced primarily the structure of expenditures on healthcare. Between 2010 and 2014, the expenditures in the healthcare sector had a downward trend. Unfortunately, the same downward trend from 2011 onwards was also generated by revenues. The economy had many other problems as well. In 2011 and 2012, it faced almost $4 \%$ inflation, which subsequently changed into deflation after 2013. The negative situation in the health sector changed as a result of the gradual economic recovery in 2012 (Statistical Office of the Slovak Republic, 2020).

In 2014 and 2015, Slovakia was again approaching the European average in terms of percentage of GDP spending on healthcare. In 2016, Slovak healthcare expenditures have even exceeded the European average and also the Czech economy in terms of expenditure as a percentage of GDP. Unfortunately this trend was not continued in 2017. (EUROSTAT, 2020). Table 1 shows the structure of government health expenditure as a percentage of gross domestic product. At the same time, a significant part of these expenditures in individual areas of health care is subject to tendering. From the budget point of view, the Slovak healthcare sector will spend the most on the area of Hospital services (3.1-3.3\% of GDP) and on Outpatients services (2.2-2.3\% of GDP). The third major type of expenditure is Medical products, appliences and equipment (1.4-1.5\% of GDP). Only $0.3-0.4 \%$ of GDP is spent on not elsewhere classified health. Within the public budgets of the Ministry of Health, the Slovak Republic does not deal with expenditures in the areas of Public health services and R\&D Health. 
Figure 1. General government expenditure development in percentage of GDP across EU 28, Czechia and Slovakia

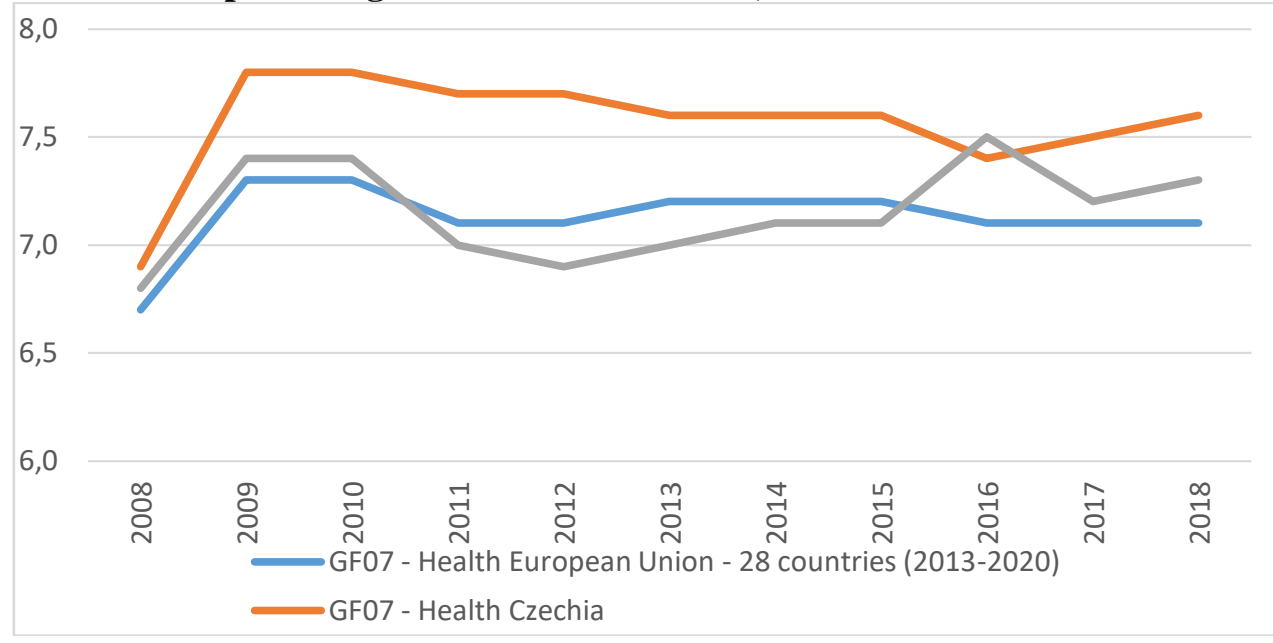

(Source: authors' own elaboration based on the data from EUROSTAT: General government expenditure by function (COFOG) online (EUROSTAT, 2020)

Table 1. Structure of Slovakia's General government expenditure by function (COFOG) - GF07 Health

(Percentage of gross domestic product - GDP)

\begin{tabular}{|c|c|c|c|c|c|c|c|c|c|c|c|}
\hline & 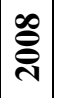 & હે & 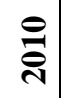 & $\overline{\bar{\nabla}}$ & 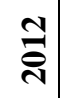 & $\stackrel{m}{\bar{\ominus}}$ & 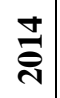 & $\stackrel{n}{\stackrel{n}{8}}$ & $\underset{\widetilde{N}}{\stackrel{0}{0}}$ & $\overline{\bar{N}}$ & $\stackrel{\infty}{\tilde{ల}}$ \\
\hline GF07 - Health & 6.8 & 7.4 & 7.4 & 7.0 & 6.9 & 7.0 & 7.1 & 7.1 & 7.5 & 7.2 & 7.3 \\
\hline $\begin{array}{l}\text { GF0701 - Medical products, appliances } \\
\text { and equipment }\end{array}$ & 1.7 & 1.8 & 1.8 & 1.7 & 1.7 & 1.7 & 1.4 & 1.4 & 1.5 & 1.5 & 1.5 \\
\hline GF0702 - Outpatient services & 1.9 & 1.9 & 2.0 & 1.9 & 1.9 & 2.0 & 2.2 & 2.3 & 2.3 & 2.2 & 2.1 \\
\hline GF0703 - Hospital services & 2.7 & 3.3 & 3.1 & 3.0 & 2.9 & 3.0 & 3.1 & 3.1 & 3.3 & 3.1 & 3.3 \\
\hline GF0704 - Public health services & 0.0 & 0.0 & 0.0 & 0.0 & 0.0 & 0.0 & 0.0 & 0.0 & 0.0 & 0.0 & 0.0 \\
\hline GF0705 - R\&D Health & 0.0 & 0.0 & 0.0 & 0.0 & 0.0 & 0.0 & 0.0 & 0.0 & 0.0 & 0.0 & 0.0 \\
\hline GF0706 - Health n.e.c. & 0.5 & 0.3 & 0.3 & 0.3 & 0.3 & 0.2 & 0.3 & 0.3 & 0.3 & 0.4 & 0.4 \\
\hline
\end{tabular}

(Source: EUROSTAT: General government expenditure by function (COFOG) online (EUROSTAT, 2020)

Slovakia is governed by the Public Procurement Act no. 343/2015, which defines the procedures and principles in public procurement for contracting authorities. The Act states the efficiency and economy of public procurement, but neither the law nor the related declarations and methodological guidelines define a specific methodology for measuring efficiency and economy. This methodology is also not defined at the international level. Public procurement has a vital role to 
play in the economy as it is an essential tool for distributing a significant proportion of public expenditure. The basic principles of public acquisition are transparency, equal treatment and open competition. One of the advantages of transparent public procurement is the lack of corruption, which is achievable through compliance with all legislative processes. The principle of nondiscrimination is closely linked to transparency. The selection of certain evaluation criteria plays a key role in the evaluation of public procurement processes in practice (Gavurová et al. 2018). The contracting authority may choose either the evaluation criterion in the form of the lowest bid or the alternative option of selecting the multi-criteria evaluation of the offers so-called economic advantageousness of the offer (Ochrana and Pavel, 2013).Evaluation of tenders based on multi-criteria and non-price criteria, which also includes an assessment of the quality of performance, is commonly carried out in the several EU Member States (Kováčik, 2018). Non-member countries prefer non-price assessment criteria even more strongly and often set the weight of the lowest bid price well below $50 \%$. In Slovakia, the lowest price is most often applied in practice as the only criterion for evaluating bids. The fact that public procurement remains a very vulnerable area in terms of corruption has not changed significantly even after EU accession. Throughout many public tenders, direct conflicts of interest, biased decision-making and clientelistic networks have emerged that work effectively. This generally persistent problem can be clarified in other sectors, e.g. in the construction sector for which public procurement is the primary source of revenue. For many large construction companies, procurement often accounts for more than half of all orders. With the availability of European funds, the share of public contracts in the total number of all contracts, as well as their financial volume, is continuously increasing (Pavel et al., 2005). These consistent facts motivated our research to analyze and evaluate the impact of the number of public procurement tenders involved in public health procurement on the final purchase price. The structure of the paper is as follows: in the introduction part, we provide an overview of international and national research studies, which presents the issue of public procurement of selected or specific types of health technologies, as well as innovative processes and the societal importance of public procurement in selected countries. In the analytical part, three methods were applied, the choice of which was determined by the character of the data and the aim of the study. The results were summarized in the discussion section and helped to create a compact quantitative framework of the examined issue. The results of the study will support the development of national and international benchmarks in this area and are a valuable platform for the development of regional strategic and development plans as well as concepts aimed at sectoral efficiency.

\section{Literature review}

The economic importance of public procurement processes is evidenced by the results of many international and national research studies. The nature of public 
procurement processes also implies the heterogeneity of research studies, giving rise to a problematic unification of their results. Despite this fact, research studies provide us with the relevant evidence of the economic benefits of procurement processes and clarify the new causal context that may be subject to follow-up and significant comparative analyzes.

Weszl et al. (2019) point out in their study the importance of a recent update of the European Union (EU) regulation on public procurement, which has led to progress in the purchase of medical devices. The authors deal with patientreported outcome measures (PROMs), which may serve as additional tools for manufacturers to demonstrate value beyond traditional metrics of safety and performance and to differentiate their products in the market of increasing competition. The results of the study show that clinical studies of selected device categories are predominantly done in Western EU nations and increasingly include PROMs. In the United Kingdom, 121 (65\%) study, out of 186 included PROMs, and in Germany, 92 (52\%) out of 178 between 1998 and 2018. Few device studies were done in the Central and Eastern European region, and 27 (35\%) out of 77 studies included PROMs. The conclusions show the importance of using PROMs and interpreting their results concerning the purchase of medical devices, which also affects the competitiveness processes. Qendri et al. (2018) examined the procurement parameters related to the procurement of HPC vaccination. The cost of a vaccine is one of the most influential metrics in the economic evaluation of HPV vaccination programs. The authors used data from 178 procurements announced in 15 European countries. HPV vaccine procurement is widely used across Europe.The fourfold decrease in the average tender-based prices compared to the list prices confirms the potential of tendering as an effective costcontainment strategy, expanding the indications for cost-effective HPV vaccination to previously ineligible target groups. Mudyarabikwa et al. (2017) stress the importance of public-private partnerships (PPPs) and their role in improving the procurement procedures of primary healthcare physicians. PPPs have been developed to enhance the quality of healthcare and patient satisfaction. The authors used 25 interviews with public and private sector employees to identify six areas of health benefits: quality improvement, improved risk management, reduced procurement costs, increased efficiency, community participation and sustainable investment. The authors state that it is essential for the success of PPPs to align their business principles to government objectives. Fuentes-Bargues et al. (2019) researched current practices and the state of green public procurement enabling the identification of areas that can be improved, as well as opportunities to improve the tendering procedures from an environmental point of view. In total, 967 processes were analyzed for calls made by municipalities for the period $2016-2017$. The results of this study show that the environmental criteria are $19.7 \%$, and the average weight is 4.1 out of 100 . The study's findings appeal to encourage plans to improve Green Public Procurement.

Oruezabala \& Rico (2012) examined the impact of the sustainable acquisition on the management of suppliers in French hospitals. Based on the 
results of the analyzes, they conclude that environmentally responsible strategies can contribute to competitive advantage and excellent financial performance. Few research studies confirm that businesses can simultaneously achieve the three interrelated objectives of economic prosperity, environmental protection and social equality. In their research Hughes et al. (2019) focus on how governance and social responsibility concerning labour standards work in the context of public sector procurement. The authors evaluate the emergence of ethical trading programs involving labour standards in the UK public sector sourcing, drawing on examples from health, higher education, construction and transportation sectors, and methodology combining interviews with participant observation. The authors state in their findings that ethical public procurement is shaped and often constrained. They also state that ethical sourcing is significantly less advanced in the UK public sector than in consumer goods. Kohler et al. (2015) in his review of procurement and pricing transparency practices for pharmaceutical products.The authors specifically focus on Brazil and examine its approach to increasing pricing transparency, to determine the level of effectiveness in lower prices using a tool (Banco de Preços em Saúde - BPS) that only reveals purchase prices as compared to other tools ( in other countries). Pricing data for 25 medications that met specific research criteria were evaluated. Separate regression models (19 models) were created for each medicine. Each model controlled for the state variable and the interaction between state and time, in order to accommodate expected heterogeneity in the data. Based on the results of comparative analyzes, it has not been shown that the use of BPS leads to a continuous reduction in the purchase prices of some of the most commonly used medicines. However, it has led to increased transparency and awareness of the purchase prices of medicines in Brazil. According to some authors, public procurement also has an impact on the elimination of inequitable access to medicines. These results are also shown by the Kotwani study (2013), which surveyed to investigate the cost, availability and affordability of fifty essential medicines in the public and private sector in Delhi, India using standardized WHO / HAI methodology. The procurement price of surveyed medicines was $0.53-0.82$ times the international reference price-IRP. The results of the study show that the acquisition prices of surveyed medicines were reasonable in comparison to IRP. However, variation in procurement prices of certain medications by different public procurement agencies was noted. The availability of medicines was very poor in public sector facilities, which are the primary source of free medication for the majority of India's low-income population. Availability of medicines is better in private retail pharmacies, but affordability remains a big challenge for the majority of the people. Price discrimination has also been investigated by Crea et al. (2019) in the Italian medical device industry. The authors used econometric analysis and Bayesian network analysis to verify if price dispersion is due to price discrimination. They point out that ASLs (Aziende Sanitarie Locali) incur higher procurement costs than AOs (Aziende Ospedaliere), which purchase larger quantities as Centralized purchasing agencies do. Consequently, second-degree price discrimination may be 
one of the causes of price differences. At the end of the study, the authors present essential findings that price levels are also inversely related to product age because of intense innovative activity, making product differentiation more likely than price discrimination. In their study, Stenius and Storbjork (2020) examine recent procurement regulations in four Nordic countries from the point of view of addiction treatment. The implementation of public acquisition in this field can be viewed as a domain struggle between the market logic and the welfare logic. Procurement regulations are now markedly different in the four countries. In the market-oriented welfare regimes, public procurement is one of the most important instruments for influencing who produces which services. The authors conclude that it is challenging to introduce substantial requirements for the protection of the welfare and population health in the procurement of social services. Chmelová and Štípek (2017) analyze the development of the market of public procurement in the Czech Republic in the years 2008-2015 in connection with the adoption of new legislation relating to the Act on Public Procurement no. 137/2006. The authors examined legislative changes (transparency, increase in competition powers and effective price enforcement) examined from the viewpoint of selected parameters of the procurement market. Their findings indicate that the transparency in terms of reducing the use of the restricted procedure of public procurement improved and the share of public contracts under the new Act on Public Procurement increased immediately after the new legislation.Kabir and Ghazali (2009) examined the risks associated with long-term concession contracts related to the Private Finance Initiative (PFI) projects, such as the National Health Service (NHS) hospitals. The authors tested several methods to eliminate project-related risks while also identifying several risks related to procurement processes. According to the authors, it is of great importance to investigate and test methods already in the process of identifying risks that could effectively manage risks. Such investigation and testings require experience in the application and use of several management methods. Aspects of Green and Sustainable Public Procurement have also been researched by Sönnichsen and Clement (2020), who provides a comprehensive review of preliminary publications on Green and Sustainable Public Procurement from 2000 until now. The authors explain how awareness and knowledge of circular public acquisition attributes, based on circular policy and strategy implementation, are essential to conducting circular public procurement. AdjeiBamfo et al. (2019) examine sustainable Public Procurement factors in developing countries that are progressively developing their e-government structures, despite lower national income. The author appeals to the fact that currently, there is very little knowledge about how electronic and internet technologies can be leveraged to stimulate sustainable supply chain management, especially Sustainable Public Procurement practices. The conclusions of his study have significant implications for promoting sustainability in the downstream supply chain practices in public sector organizations in the developing country context. Similar research ambitions were in the study of Plaček et al. (2020). They aimed to analyze the factors of public procurement in low-performing European countries.In this way, it is 
possible to quantify not only sectoral disparities within the country but also the impact of the country's economic potential on the implementation of innovative practices in public procurement processes, reflecting on the necessary institutional aspects. Milovanovic et al. (2014) identified three steps in the medication procurement process where the role of clinical pharmacologists is essential and useful: creating a list of medications, selecting the most appropriate offers, and analyzing the selection process and results. As they state in their study, providing affordable, effective and high-quality medicines for transition countries is a particularly difficult task. The medicine offerings are resource-intensive, risky and challenging work. Aggregation of individual tenders at a national or regional level is probably the best option for hospitals in transition countries. Ochrana and Pavel (2013) analyzed in their study the award of public contracts for work, supplies and services by randomly chosen contracting authorities from the local self-government level in the Czech Republic. The authors analyzed 175 contracts concluded with subjects of local self-government in the Czech Republic. The results of the analysis confirmed the positive effect of open tenders on the level of competition on the supply side and pointed out the dominant use of price criteria in public procurement. In the conclusion of the study, the authors evaluate that the main problem of the public procurement market in the Czech Republic is the relatively low competence of administrators who are not able to use non-price criteria more often. Grega and Nemec (2015) examined the impact of competitiveness on public procurement results. They used data from public procurement of the Slovak Republic for 2010-2014. As they point out in their results, competitiveness has a significant impact on the final price, but also the use of the lowest price criterion and EU funding can affect the final cost of acquisition. Slovakia's competitiveness in public procurement is lower compared to the Czech Republic. It is also evidenced by the results of the study by Zachar and Dančíková (2014), which confirm that public procurement currently plays an important role. Still, in the health sector, the number of tenders in public procurement is far behind.

The results of many research studies support the creation of an international and national comparison platform and the development of benchmarks in this area (Šumpíková and Duurčeková, 2019). They are essential not only for the scientific research field but also for practitioners and policymakers.

\section{Data and Methodology}

To achieve the objective of the research, we used a database from the available Journal of the Government Office of the Slovak Republic. We analyzed a total of 1544 public procurement contracts for the period 2014-2017, and we were interested in the data on the number of tenders in individual years, the data on estimated and final prices. Table 2 gives an overview of the number of tenders with basic projected and final price data. 
Table 2. Descriptive statistics of variables

\begin{tabular}{|c|c|c|c|c|}
\hline Year & $\begin{array}{c}\text { Number of } \\
\text { contracts }\end{array}$ & $\begin{array}{c}\text { Average number of } \\
\text { offers }\end{array}$ & $\begin{array}{c}\text { Average estimated } \\
\text { price }\end{array}$ & $\begin{array}{c}\text { Average final } \\
\text { price }\end{array}$ \\
\hline 2014 & 501 & 2.157685 & 547688.2 & 534068.3 \\
\hline 2015 & 399 & 1.892231 & 1001904.0 & 971403.3 \\
\hline 2016 & 406 & 2.938424 & 424565.6 & 420165.7 \\
\hline 2017 & 238 & 2.197479 & 215079.3 & 207954.3 \\
\hline
\end{tabular}

(Source: Authors calculation)

For each contract, an indicator was calculated based on the final price to projected price ratio to define whether it keeps an overprived or underpriced status, or whether the public procurement did not affect the price change (final price/projected price). If the rate is greater than 1, this means that the final price is higher than the expected price, the public procurement has caused overpricing. If the rate is less than 1, the final price is lower than the projected price, and we have achieved savings through public procurement. If the rate equals 1 , this means that the final and the projected price are equal, and the procurement had no influenceon the price.

\section{Figure 2. Descriptive statistics of variables - Proportion of bids submitted}

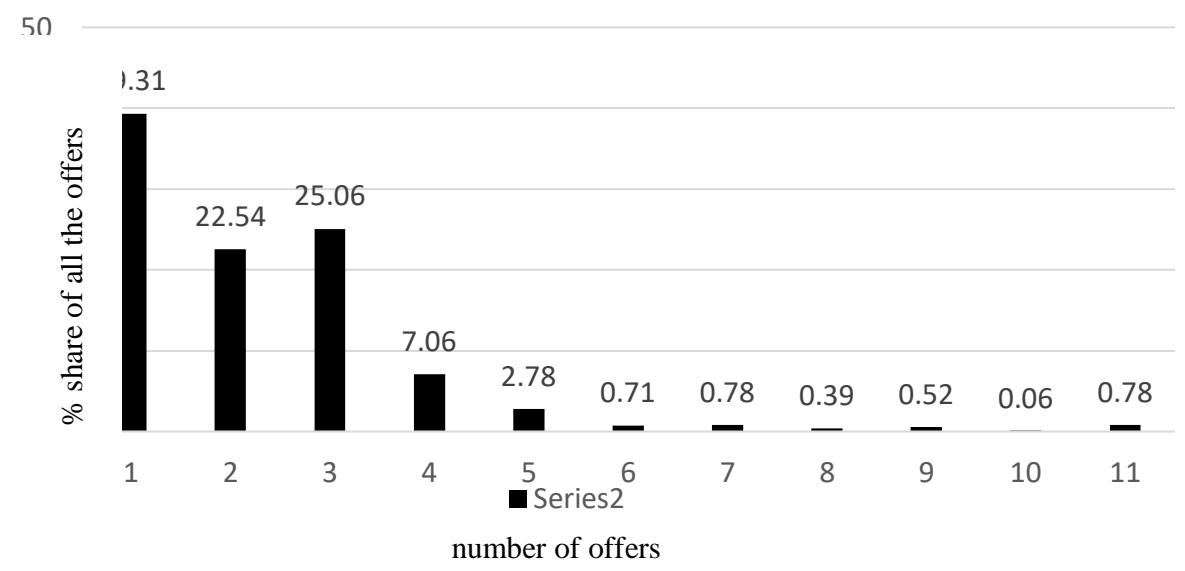

(Source: created by the authors)

Figure 2 represents the percentage of individual tenders submitted out of their total volume for the aggregated period 2014-2017. We can see that the highest share is represented by contracts with only one offer, amounting to more than $39 \%$. This also means that more than a third of the tenders submitted did not have to face further competition in public procurement. One-quarter of the total share consisted of the tenders with three bids, followed by tenders with two bids $(22.54 \%)$. There were also tenders with thirteen tenders submitted, but their number was only $12 \%$ of the total of 1544 contracts. We also looked at how much 
savings or overpricing could be achieved based on a specific number of offers. We assume that the growth in the number of offers increases savings. Observations were divided into five groups based on the achieved savings or overcharge, whilst without change rate is equal to 1 :

- savings: rate is from interval $(0,5 ; 1)$,

- high savings: rate less than or equal to 0.5 ,

- overpricing: rate is from interval $(1 ; 1,5)$,

- high overpricing: the rate is greater than or equal to 1.5.

In these groups we receive the following average number of offers (Table 3):

Table 3. Average number of offers submitted

\begin{tabular}{|l|c|}
\hline \multicolumn{1}{|c|}{ Group } & Average number of offers \\
\hline Without a change & 1.86 \\
\hline Savings & 2.41 \\
\hline High savings & 4.09 \\
\hline Overpricing & 2.17 \\
\hline High overpricing & 2.58 \\
\hline
\end{tabular}

(Source: Authors calculation)

Subsequently, the average value of this rate was calculated every year as the average value of the rates for a single year. On average, savings were achieved in all the years 2014-2017 (Table 4), as this average rate is below threshold 1. The average savings in each year are shown in Table 4.

Table 4. Average savings achieved in individual years

\begin{tabular}{|c|c|}
\hline Year & Average savings in \% \\
\hline 2014 & 5.90 \\
\hline 2015 & 4.81 \\
\hline 2016 & 5.63 \\
\hline 2017 & 4.25 \\
\hline
\end{tabular}

(Source: Authors calculation)

\section{Analysis of the research results and main findings}

The analytical part is divided into the three parts, depending on the methods used. In the first part, we used a generalized linear model; in the second quantile regression, in the third part, a generalized model was created for each year of the reviewed period. 


\subsection{Modelling the relationship between the size of savings and the number of offers in public procurement in 2014-2017 using a generalized linear model}

Since abnormalities are caused by extremely large overpricing, is is appropriate to apply linear regression, we would have to exclude these extreme samples from observation, which, on the other hand, could affect the results. For this reason, we used a method that is robuster than linear regression and does not require such strict assumptions. The generalized linear model is employed. In modelling, the relationship between the size of the savings and the number of offers using a generalized linear model is examined, the aim was to quantify the explanatory variable of the growth in the number of suggestions for creating savings or overpricing in public procurement. The analysis was performed in the environment of the statistical programming language $\mathrm{R}$ using the integrated library statistics. In our analysis, we used Generalized linear model with Gamma family and log link (Multiplicative arithmetic mean model). As the outcome is skewed and always positive, it can be modelled by a gamma distribution. The function is the following:

$$
\ln E[y]=\beta_{0}+\beta_{1} x(1)
$$

Where $\mathrm{y}$ is the variable of the final price and the projected price and $\mathrm{x}$ is the variable the number of offers. The following is also applied to the model:

$$
E[y]=e^{\beta_{0}+\beta_{1} x}
$$

Taking into account the properties of the logarithmic function and meeting its condition the outcome on the right is skewed and always positive. Equation 2 can be transformed into the form:

$$
E[y]=e^{\beta_{0}} e^{\beta_{1} x}
$$

This relationship will help us to interpret the estimated regression coefficients. The influence of individual variables determined by regression coefficients must be calculated using the exponential function. In our case, we have only one explanatory variable, and we want to quantify the growth in the number of tenders for saving or overpricing in public procurement (Table 5).

Table 5. Final price as a percentage

\begin{tabular}{|l|c|c|}
\hline & \multicolumn{2}{|c|}{ Final price as a \% of the estimated price } \\
\hline Explanatory variables & Estimated coefficient coefficient & Statistical significance \\
Constant & 0.001728 & 0.882 \\
\hline Number of bids & -0.024764 & $2.11 .10^{-9} * * *$ \\
\hline
\end{tabular}

(Source: Authors calculation) 
The regression coefficients $b_{0}$ and $b_{1}$ themselves are not interpreted. To interpret them, we have to calculate them using the exponential function:

$$
\begin{gathered}
e^{\beta_{0}}=e^{0.001728}=1.0017297 \\
e^{\beta_{1}}=e^{-0.024764}=0.9755406
\end{gathered}
$$

We interpret the impact of the number of offers on average savings or overpricing. With an increase in the number of proposals by one offer, the rate of final to estimated price will change for an average 0.9755406 times, which means that it will decrease by approximately $2.45 \%$. Since this is a rate of final and projected price, this can be interpreted as an increase in savings of $2.45 \%$. The increase in the number of bids by one unit has an impact on the average increase in procurement savings of $2.45 \%$.

3.2 Modelling the relationship between the size of savings and the number of tenders in public procurement in 2014-2017 using quantile regression

At the same time, in public procurement practice, in particular, in the health sector, it may happen that the number of tenders is otherwise responding to highly overpriced or otherwise saving contracts. For this reason, we used quantile regression, where instead of the conditional mean value, we model the effect of the explanatory variables on the individual quantiles of the explained variable; and there is no need to assume the normality of the distribution of the entire error component, resulting in some form of robustness. The analysis was performed in the environment of the statistical programming language $\mathrm{R}$ using the quantreg library. We gradually consider $25^{\text {th }}, 30^{\text {th }}, 35^{\text {th }}, \ldots 75^{\text {th }}$ quantile of the explained variable (the size of saving or overpricing in public procurement as a ratio of final and projected price). The results of quantile regression are shown in Table 6.

Table 6. Individual quantiles of the explained variable

\begin{tabular}{|r|r|r|r|r|}
\hline \multirow{2}{*}{$\tau$} & \multicolumn{2}{|c|}{ Constant } & Final price as a \% of the estimated price \\
\cline { 2 - 5 } & $\begin{array}{l}\text { Estimated } \\
\text { regression } \\
\text { coefficient }\end{array}$ & $\begin{array}{c}\text { Statistical } \\
\text { significance }\end{array}$ & $\begin{array}{l}\text { Estimated } \\
\text { regression } \\
\text { coefficient }\end{array}$ & $\begin{array}{c}\text { Statistical } \\
\text { significance }\end{array}$ \\
\hline 0,25 & 1.01640 & $0.000 * * *$ & -0.04765 & $0.000 * * *$ \\
\hline 0.3 & 1.02345 & $0.000 * * *$ & -0.04198 & $0.000 * * *$ \\
\hline 0.35 & 1.02621 & $0.000 * * *$ & -0.03499 & $0.000 * * *$ \\
\hline 0.4 & 1.02470 & $0.000 * * *$ & -0.02922 & $0.000 * * *$ \\
\hline
\end{tabular}


Evaluation of selected determinants of public procurement in the health sector

\begin{tabular}{|r|r|r|r|r|}
\hline \multirow{2}{*}{$\tau$} & \multicolumn{2}{|c|}{ Constant } & Final price as a \% of the estimated price \\
\cline { 2 - 5 } & $\begin{array}{r}\text { Estimated } \\
\text { regression } \\
\text { coefficient }\end{array}$ & $\begin{array}{c}\text { Statistical } \\
\text { significance }\end{array}$ & $\begin{array}{c}\text { Estimated } \\
\text { regression } \\
\text { coefficient }\end{array}$ & $\begin{array}{c}\text { Statistical } \\
\text { significance }\end{array}$ \\
\hline 0.45 & 1.02596 & $0.000 * * *$ & -0.02648 & $0.000 * * *$ \\
\hline 0.5 & 1.01962 & $0.000 * * *$ & -0.01962 & $0.000 * * *$ \\
\hline 0.55 & 1.01333 & $0.000 * * *$ & -0.01333 & $0.000 * * *$ \\
\hline 0.6 & 1.00731 & $0.000 * * *$ & -0.00731 & 0.23105 \\
\hline 0.65 & 1.00372 & $0.000 * * *$ & -0.00372 & 0.33275 \\
\hline 0.7 & 1.00067 & $0.000 * * *$ & -0.00067 & 0.74366 \\
\hline 0.75 & 1.00000 & $0.000 * * *$ & 0.00000 & 1.00000 \\
\hline
\end{tabular}

As shown in Table 5, with the increase in $\tau$ (quantile order), the effect of the number of offers on the creation of savings in public procurement is gradually decreasing. For $40 \%$ or more of the most overpriced orders $(\tau=0.6 ; 0.65 ; \ldots)$, the number of proposals does not have a statistically significant effect on the size of the savings. On the other hand, we achieve $4.77 \%$ savings in $25 \%$ of the most cost-effective orders, with a one-unit bid increase. The results obtained by quantile regression, however, allowed us to model this dependence on the various quantiles of the variable explained, thereby getting values of this savings of $4.77 \%$ for the $25 \%$ most cost-effective orders to a statistically insignificant change for $40 \%$ or more of the most overpriced orders. The function of the quantile regression coefficients together with the confidence intervals of the estimation of these coefficients is shown in Figure 3.

As the ranking order of the regression quantiles, the saving effect due to the rise in the number of offers gradually decreases. The red lines show the estimate of the regression coefficient along with the confidence intervals if all the orders are considered together, regardless of the quantile of the variable explained, using the generalized linear regression model from the previous chapter. 
Figure 3. The function of the quantile regression coefficients together with the confidence intervals of the coefficient estimation

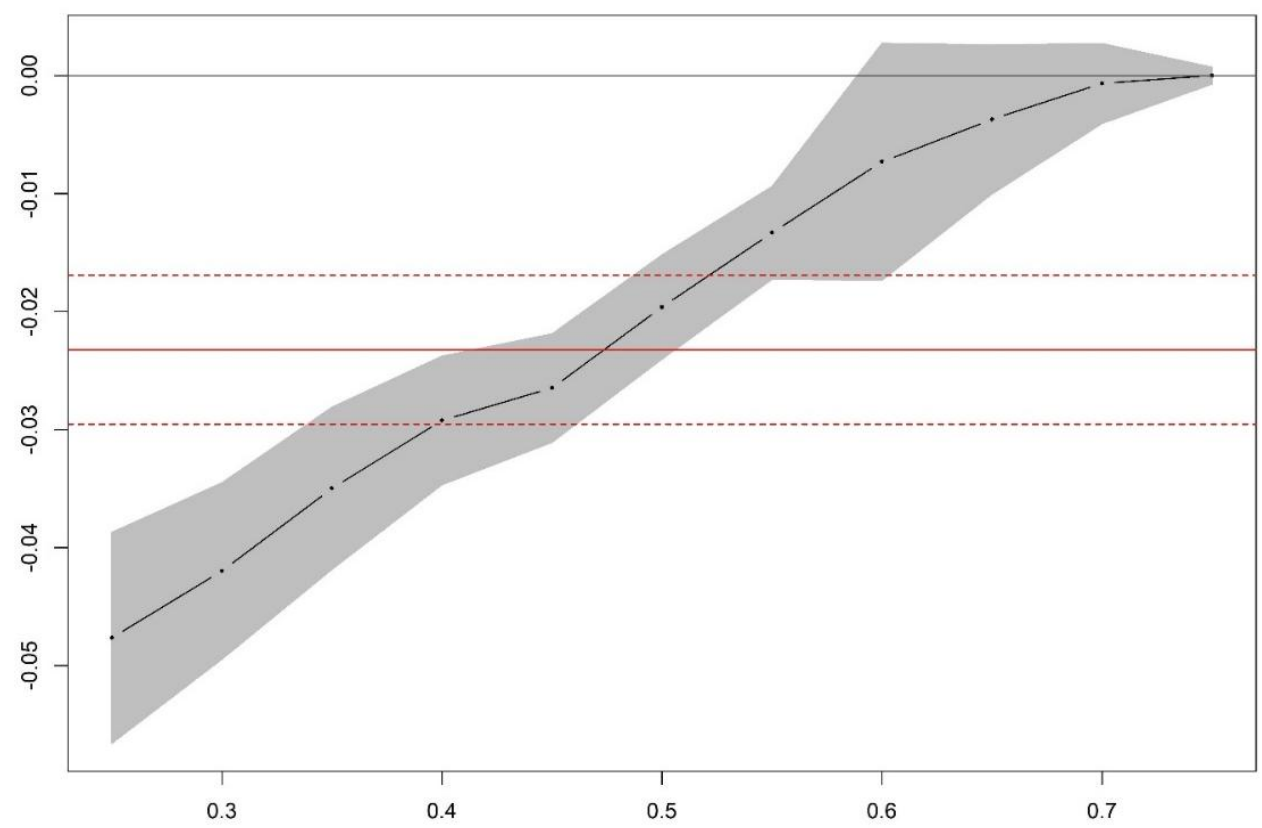

(Source: created by the authors)

\subsection{A generalized model for each year of the reviewed period}

As the analysis in section 3.1 shows, the increase in the number of offers by one unit has an impact on the average increase in procurement savings of $2.45 \%$ over the whole analysis period (aggregated data for 2014-2017). Increasing the number of tenders to create savings in public acquisition can change over time. For this reason, we have applied a generalized linear model to partial data depending on the year to which it belongs. The results are shown in Table 7-Table 10.

Table 7. Results of the generalized linear model for 2014

\begin{tabular}{|l|r|r|}
\hline \multirow{2}{*}{ Explanatory variables } & \multicolumn{2}{|c|}{ Final price as a \% of the estimated price } \\
Estimated regression & Statistical significance \\
\hline Constant & 0,094171 & $1,46.10^{-6} * * *$ \\
\hline Number of bids & $-0,074215$ & $<2.10^{-16} * * *$ \\
\hline \multicolumn{2}{|c}{ (Source: Calculated by the authors) }
\end{tabular}




$$
e^{\beta_{1}}=e^{-0.074215}=0,928472
$$

In 2014, the increase in the number of offers by one unit affected the average increase in public procurement savings by $7.15 \%$.

Table 8. Results of the generalized linear model for 2015

\begin{tabular}{|l|r|r|}
\hline \multirow{2}{*}{ Explanatory variables } & \multicolumn{2}{|c|}{ Final price as a \% of the estimated price } \\
& Estimated regression coefficient & Statistical significance \\
\hline Constant & -0.019352 & 0.2062 \\
Number of bids & -0.015948 & $0.0194 *$ \\
\hline
\end{tabular}

(Source: calculated by the authors)

$$
e^{\beta_{1}}=e^{-0.015948}=0,9841783
$$

In 2015, an increase in the number of offers by one unit had an impact on the average increase in procurement savings of $1.59 \%$.

Table 9. Results of the generalized linear model for 2016

\begin{tabular}{|l|r|r|}
\hline & \multicolumn{2}{|c|}{ Final price as a \% of the estimated price } \\
\hline Explanatory variables & Estimated regression coefficient & Statistical significance \\
Constant & -0.029107 & 0.407 \\
\hline Number of bids & -0.009888 & 0.303 \\
\hline
\end{tabular}

(Source:calculated by the authors)

$$
e^{\beta_{1}}=e^{-0.009888}=0.9901607
$$

In 2016, the increase in the number of offers did not have a statistically significant impact on the average increase/decrease in savings in public procurement.

Table 10. Results of the generalized linear model for 2017

\begin{tabular}{|l|r|r|}
\hline & \multicolumn{2}{|c|}{ Final price as a \% of the estimated price } \\
\hline Explanatory variables & Estimated regression coefficient & Statistical significance \\
Constant & -0.0001046 & 0.993645 \\
\hline Number of bids & -0.0198342 & $0.000189 * * *$ \\
\hline
\end{tabular}

(Source:calculated by the authors)

$$
e^{\beta_{1}}=e^{-0.0198342}=0,9803612
$$

In 2017, the increase in the number of bids by one unit affected the average increase in procurement savings of $1.96 \%$. Results of all models were interpreted under conditions of ceteris paribus. 


\section{Discussions and conclusions}

Public procurement continues to play an important role in the health sector, and the average number of tender tenders in hospitals remains lagging in comparison with other sectors of the economy in Slovakia. The link between the impact of the number of offers submitted and the price of the contracts concluded is confirmed by many empirical studies (Ochrana \& Maaytová, 2012; Pavel \& Sičáková-Beblavá, 2008; Strand et al., 2011), which the authors have demonstrated the existence of an inversely proportional relationship between the number of tenders submitted and the price of the contract in. It is therefore in the interest of the public sector to obtain as many competition contracts as possible despite some increase in administrative costs, as the impact on the size of administrative costs is relatively small compared to price reductions (Ochrana \& Pavel, 2013). Higher competition within healthcare facilities could also bring significant savings and a more efficient allocation of resources to the healthcare sector.

The paper aims to examine the impact of the number of public procurement tenders in the healthcare sector on the final purchase price. We used data from 1544 public contracts related to the procurement of health technologies for 2014-2017. The highest number of public contracts was reached in 2014 (501); the lowest number (238) was achieved in 2017. The highest average value of projected and final price found in 2015. The proportion of tenders submitted with only one tenderer was over $39 \%$. This means that more than a third of the tenders submitted did not have to face further competition in the procurement during the period considered. We anticipated that the increase in the number of offers would lead to a rise in savings. This is confirmed by the first regression model. The highest average number of bids was recorded in the high-savings order group, the lowest average number of offers - in the order group without change and the impact of public procurement. On average, savings were achieved in all the years examined, as the average rate was below 1 . The average savings amounted to $5.90 \%$ in 2014 , $4.81 \%$ in $2015,5.63 \%$ in 2016, and a value of $4.25 \%$ in 2017 . We used a generalized linear model and quantile regression for analysis. The results pointed out that, as the number of bids increased by one, on average, the final / predicted price ratio would change 0.975 times, which means a $2.45 \%$ level of savings.Using quantile regression, we modelled the effect of the explanatory variables on the individual quantiles of the explained variable instead of the conditional mean. The aim was to determine the impact of the number of bids at each overcharge level. As the value of the quantile increases, the effect of offers on generating savings in public procurement is gradually decreasing. For more than $40 \%$ of the most overpriced orders, the number of proposals does not have a statistically significant effect on the size of the savings. With $25 \%$ of the most economical orders with an increasing number of bids by one unit, savings of $4.77 \%$ were achieved. Increasing the number of procurement contracts to create savings in public procurement may have different developments over time. By applying the generalized linear model, we found that in 2014 the increase in the number of bids by one unit had an impact 
on the average increase in public procurement savings of $7.15 \%$. In 2015 , this impact fell to $1.59 \%$. In 2016, the growth in the number of bids did not have a statistically significant impact on the average increase or decrease in savings. In 2017, this value increased slightly above $1.96 \%$. Procurement processes will continue to be a very important partin a process of the efficient allocation of public expenditure. This is also due to the fact that the private sector can produce some goods and services much cheaper than the public sector. To get the most out of these benefits, it is essential to have transparent procurement procedures that significantly reduce the scope for corruption. It is essential to place a strong emphasis on the transparency of the procurement processes, with more substantial suppression of corruption and clientelism. This will result in effective resource allocation and higher sectoral efficiency.

\section{Authors Contributions}

Conceptualization, Beata Gavurova; Data curation, Martin Mikeska; Formal analysis, Eva Huculova and Beata Gavurova; Methodology, Martin Mikeska; Software, Eva Huculova; Visualization, Beata Gavurova; Writing original draft, Beata Gavurova and Martin Mikeska.

\section{Conflict of Interest Statement}

Authors declare that they do not have any competing financial, professional, or personal interests from other parties.

\section{Acknowledgement}

This research was funded by the Slovak Research and Development Agency under the contract No. APVV-17-0360: "Multidimensional analysis of significant determinants of public procurement efficiency with emphasis on the application of Health Technology Assessment in the procurement preparation phase".

\section{References}

Adjei-Bamfo, P., Maloreh-Nyamekye, T., Ahenkan, A. (2019). The role of e-government in sustainable public procurement in developing countries: A systematic literature review. Resources, Conservation and Recycling, 142, 189-203. https://doi.org/ 10.1016/j.resconrec.2018.12.001

Crea, G., Cacaliere, A., Cozzi, A. (2019). Price discrimination in the Italian medical device industry: an empirical analysis. Economia Politica, 36:571-608. https://doi.org/10.1007/s40888-019-00149-5

Fuentes-Bargues, J. L., Ferrer-Gisbert, P. S., González-Cruz, M. Bastande-Ceca, M. J. (2019). Green Public Procurement at a Regional Level. Case Study: The Valencia Region of Spain. International Journal of Environmental Research and Public Health, 16, 2936. https://doi.org/10.3390/ijerph16162936 
Gavurova, B., Tucek, D., Tkacova, A., Danko, J. (2018). Public procurement efficiency in agriculture and forestry in Slovakia. Administratie si Management Public, 30, 24-36. https://doi.org/10.24818/amp/2018.30-02

Grega, M., Nemec, J. (2015). Factors Influencing Final Price of Public Procurement: Evidence from Slovakia. Procedia Economics and Finance, 25, 543-551. https://doi.org/10.1016/s2212-5671(15)00768-6

Hughes, A., Morrison, E., Ruwanpura, K. N. (2019). Public sector procurement and ethical trade: Governance and social responsibility in some hidden global supply chains. Transactions of the Institute of British Geographers, 44(2): 242 255. https://doi.org/10.1111/tran.12274

Chmelová, P., Štípek, V. (2017). Analysis of the Development of the Public Procurement in the Czech Republic in the Years2008-2015. Politická ekonomie, 2017, 65(3), 316-334. https://doi.org/10.18267/j.polek.1146

Kabir, S., Ghazali, F. E. M. (2009). Determination of risk identification process employed by NHS for a PFI hospital project in the UK. Journal of Industrial Engineering and Management, 2(3). https://doi.org/10.3926/jiem.2009.v2n3.p558-568

Kohler, J. C., Mitsakakis, N., Saadat, F., Byng, D., Martinez, M. G. (2015). Does Pharmaceutical Pricing Transparency Matter? Examining Brazil's Public Procurement System. Globalization and Health, 11:34. doi: 10.1186/s12992-0150118-8

Kotwani, A. (2013). Where are we now: assessing the price, availability and affordability of essential medicines in Delhi as India plans free medicine for all. BMC Health Serv Res 13, 285. https://doi.org/10.1186/1472-6963-13-285.

Kováčik, P. (2018). Ako hodnotit' kvalitu a výhodnost’ ponúk vo verejnom obstarávaní. Eurostav, 10, 36-38.

Milovanovic, D. R., Pavlovic, R., Folic, M. et al. (2004). Public drug procurement: the lessons from a drug tender in a teaching hospital of a transition country. European Journal of Clinical Pharmacology, 60(3), 149-153.https://doi.org/10.1007/s00228 004-0736-1

Mudyarabikwa, O., Tobi, P., Regmi, K. (2017). Public - private partnerships to improve primary healthcare surgeries: clarifying assumptions about the role of private provider activities. Primary Health Care Research \& Development, 18: 366-375. https://doi.org/10.1017/s1463423617000147

Ochrana, F., Maaytová, A. (2012). Starting points for creating a transparent and noncorruption public procurement system. Ekonomický časopis, 60(7): 732-745.

Ochrana, F., Pavel, J. (2013). Analysis of the impact of transparency, corruption, openness in competition and tender procedures on public procurement in the Czech Republic. Central European Journal of Public Policy, 7(2), 114-134.

Oruezabala, G., Rico, J. C. (2012). The impact of sustainable public procurement on supplier management - The case of French public hospitals. Industrial Marketing Management, 41(4), 573-580. https://doi.org/10.1016/j.indmarman.2012.04.004

Pavel, J. et al. (2005). Veřejné zákázky v české republice: Korupce nebo transparentnost? Transparency International-Česká republika, pp. 95. https://www.transparency.cz/ verejne-zakazky-ceske-republice-korupce-transparentnost/ 
Pavel, J., Sičáková-Beblavá, E. (2008). Transparentnost' trhu verejného obstarávania. Ekonomický časopis, 56(2): 168-181.

Plaček M., Nemec J., Ochrana F., Schmidt M., Půček M. (2020) Analysis of Factors of Overpricing in Public Procurement: A Study for Low-Performing EU Countries. In: Farazmand A. (eds) Global Encyclopedia of Public Administration, Public Policy, and Governance. Springer, Cham. https://doi.org/10.1007/978-3-319-318165_3909-1

Sönnichsen, S., D., Clement, J. (2020). Review of green and sustainable public procurement: Towards circular public procurement. Journal of Cleaner Production, 245, 118901. https://doi.org/10.1016/j.jclepro.2019.118901

Stenius, K., Storvjork, J. (2020). Balancing welfare and market logics: Procurement regulations for social and health services in four Nordic welfare states. Nordic Studies on Alcohol and Drugs, 37(1) 6-31. https://doi.org/10.1177/ 1455072519886094

Strand, I., Ramada, P. Canton, E. (2011). Public procurement in Europe. PWC. http://ec.europa.eu/internal_market/publicprocurement/docs/modernising_rule s/cost-effectiveness_en.pdf

Šumpíková, M. Durčeková, I. (2019). Transaction Costs, Outsourcing, and the Public Procurement Review Process in the Czech Republic and Slovakia. NISPAcee Journal of Public Administration and Policy, 12(2): 233-250. https://doi.org/10.2478/nispa-2019-0021

Weszl, M., Rencz, F., Brodsky, V. (2019). Is the trend of increasing use of patient-reported outcome measures in medical device studies the sign of shift towards value-based purchasing in Europe? The European Journal of Health Economics, 20(Suppl 1): S133-S140. https://doi.org/10.1007/s10198-019-01070-1

Zachar, D., Dančíková, Z. (2014). Vo vel’kých nemocničných tendroch sa sút’aží málo. Analýza verejného obstarávania slovenských nemocníc v rokoch 2012-2014. INEKO.

Qendri, V., Bogaards, J. A., Berkhof, J. (2019). Pricing of HPV vaccines in European tender-based setting. The European Journal of Health Economics, 20: 271-280. https://doi.org/10.1007/s10198-018-0996-9

Zákon č. 343/2015 Z. z.Zákon o verejnom obstarávaní a o zmene a doplnení niektorých zákonov. 